\title{
Performance Assessment of Installed Arsenic Removal Technologies and Development of Protocol for Alternative Safe Drinking Water Supply Options for Arsenic Hit Areas of Pakistan
}

\author{
Islam-ul-Haque \\ Eco-Logical Sustainability Through Environment Protection Services (Eco-STEPS), Inc, Islamabad- Pakistan
}

Email address:
islamhaq3@yahoo.com

To cite this article:

Islam-ul-haque. Performance Assessment of Installed Arsenic Removal Technologies and Development of Protocol for Alternative Safe Drinking Water Supply Options for Arsenic Hit Areas of Pakistan. American Journal of Modern Physics. Special Issue: Ground Water Arsenic Contamination and Action Plan for Mitigation. Vol. 3, No. 3-1, 2015, pp. 31-42. doi: 10.11648/j.ijema.s.2015030301.14

\begin{abstract}
After identifications of arsenic contamination in Pakistan, lot of technological based arsenic mitigation interventions were carried out which could not last longer due to non-availability of filtration media and running spare parts of arsenic removal tanks units in the local market. The in-depth performance analysis of arsenic removal technology (ART) units, clay pitchers and PUR sachet was carried out which showed un-sustainability of these interventions. The main reasons are lack of awareness, illiteracy and unfavorable socio-economic conditions which make the end users in villages/rural areas the most vulnerable to the adverse impacts of any type of contaminated water and own the installed arsenic removal interventions. Therefore, before taking up any arsenic removal project, it is worthwhile to explore those interventions which are compatible to local socio-economic environments. Deeping boring options have been found best suited, as most of the agricultural practices are dependent on ground water- at shallow depths. The soil analysis at deeper depth will help in ascertaining the causes of arsenic contamination due to presence of arseno-pyrites or due to leaching of sustained applications of pesticides \& fertilizers. Therefore, in case of absence of arseno-pyrite sediments at deeper depths. Then the best option for provisioning of arsenic free water is deep boring. The active participation of the communities who are the intended beneficiaries of arsenic mitigation is vital for the success of the programme. Lack of awareness and generally unfavorable conditions are also obstacles to mobilizing communities to get the best out of community-based programmes and projects. Therefore, a well designed protocol for alternative water supply has been evolved which will help in provisioning of sustainable arsenic free water.
\end{abstract}

Keywords: Alternative Water Supply, Performance Assessment, Arsenic Removal Technologies

\section{Introduction}

Access to safe drinking water is one of the most important determinants of health and socio economic development (Nahar et al., 2008). The importance of safe water supplies has led to an emphasis on the provision of appropriate facilities in developing countries (WHO, 2001). The consumption of arsenic contaminated water causes adverse impacts on human health which in-return detoriates socio-economic status of the population. Inadequate drinking water not only results in more sickness and death, but also causes higher health care cost, low work productivity, lower school enrolment, and increased poverty. Therefore, safe drinking water is an essential component of primary health care and is imperative for poverty alleviation (Ahmad et al., 2005). Water intended for human consumption should be safe and adequate for human needs. This has been defined as "water that is free from pathogenic agents, free from harmful chemical substances, pleasant to taste, i.e. free from colour, odour, and usable for domestic purposes" (Park, 1997). The health benefits from reducing water-related disease can in some circumstances be transmuted into a greater work capacity, which may contribute to increased production and hence to overall economic development.

Long-term exposure to inorganic arsenic, mainly through 
drinking of contaminated water, eating of food prepared with this water and eating food irrigated with arsenic-rich water, can lead to chronic arsenic poisoning. Skin lesions and skin cancer are the most characteristic effects.

After identification of arsenic contamination in Pakistan, UNICEF provided support for arsenic mitigation measures for the provision of safe drinking water to the affected communities through the following available arsenic mitigation technologies;

- Arsenic Removal technology- Filter (ART)

- House hold arsenic removal filters

- $\quad$ PUR Sachet

- Deep Boring water supply (Alternative Water Source)

The emerging health problem of arsenic contamination in drinking water has mostly been observed in southern Punjab. District Rahim Yar Khan has been categorized as one of the high risk arsenic impacted area which is situated on the bank of river Indus. The most affected union councils are located very near on the Indus river i.e. Basti Rasul Pur, Rajan pur Kalan, and Bahoodi Pur qureshian. Rahim Yar khan is a prominent agriculture production land and main crops are Cotton, wheat and sugarcane which require extensive use of pesticides and fertilizers, the probable causes of ground water arsenic contamination. After confirmation of ground water arsenic contamination in district Rahim Yar Khan, all above mentioned arsenic mitigation interventions and programme were launched in the arsenic affected area, but due to devoid of technical knowhow amongst the community and non-availability of running spare parts, the subject interventions could sustained, except for deep boring option.

The major reasons were lack of community understanding about the technical maintenance of the arsenic removal technologies, i,e, periodic changes of filter media, back washing and monitoring of system efficiency and performance. The main reasons was low socioeconomic indicators (Islam et al-2012). Some of prevailing socio-economic indicators of the area are mentioned in figure-1,2,3 \& 4, below;

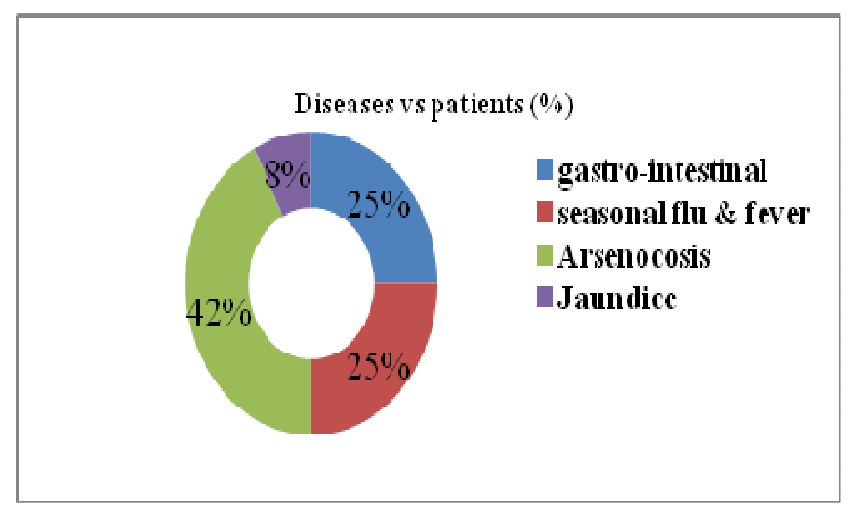

Figure 1. Comparison of prevailing diseases due to water contamination

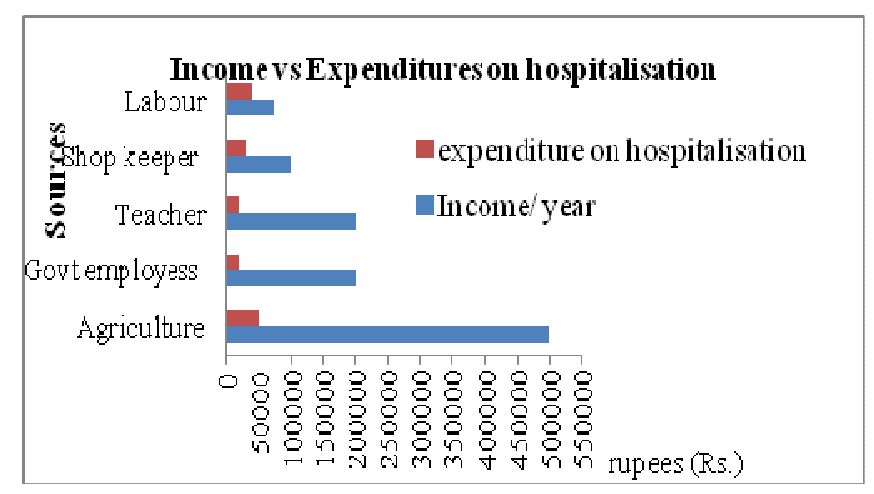

Figure 2. Income and health cost/hospitalization expenditures due to contaminated water

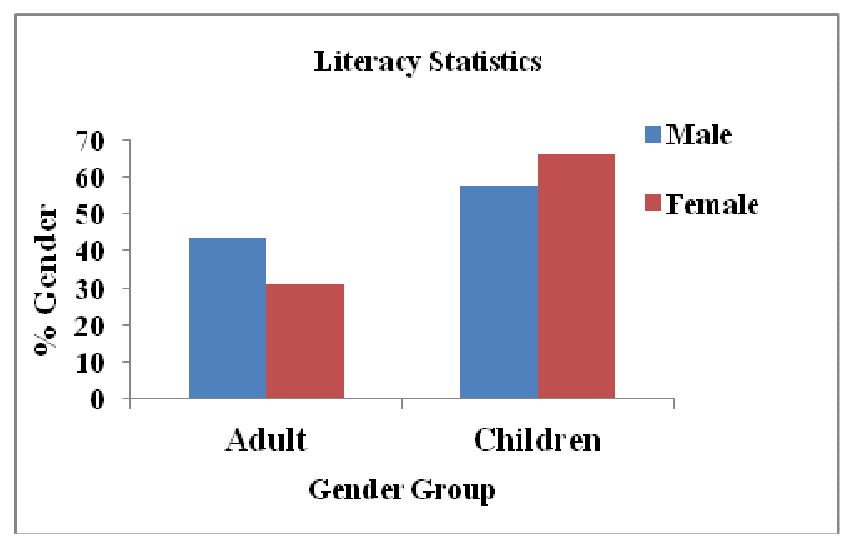

Figure 3. Prevailing literacy statistics in the area

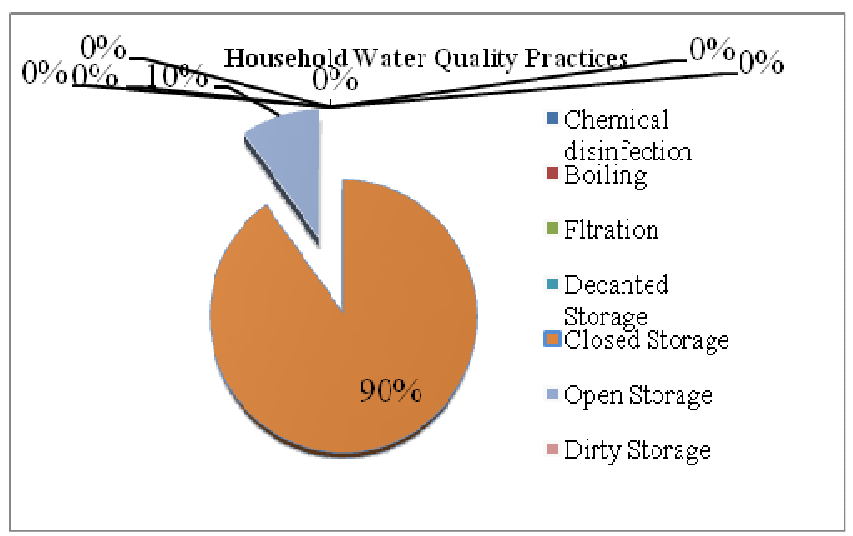

Figure 4. Water treatment practices at household levels

Therefore, keeping in view the above mentioned socioeconomic indicators, the technological based arsenic free mitigation projects may not be sustainable for a longer period of time. Thus before, going for any such intervention/project, the most sustainable alternative arsenic free water supply options be explored, for which a well designed protocol is required to make the alternative water supply options viable and sustainable, both in terms of economically and technically.

\section{Literature Review}

In Bangladesh, alternative water supply options, like dugwells (DW), deep tube-wells (DTW), pond sand filters (PSF) and rain water harvesting (RWH) interventions are in use, 
beside technological options (Md. Akramul Alam et al )being installed in arsenic affected areas under arsenic mitigation programme About 29 million people are either directly or indirectly exposed to arsenic contamination with varying degrees of risk due to extensive arsenic contamination of the groundwater in the alluvial aquifers of Bangladesh. Considering the urgency and gravity of the problem, alternative water supply options

British Geological Survey (BGS) and the Department of Public Health Engineering (DPHE) of Bangladesh conducted a study about ground water arsenic contamination which has revealed that only about one percent of deep wells having depth greater than 150 meters are contaminated with arsenic higher than $50 \mu \mathrm{g} / \mathrm{L}$ and five percent of tube-wells have arsenic content above $10 \mu \mathrm{g} / \mathrm{L}$ (the WHO guideline value). Thus, sinking of deep tube-wells in arsenic affected areas can provide safe drinking (Mustafa Moinuddin, ACDIS Occasional Paper-2004 )

\section{Objectives}

The salient objectives are as under;

3.1 To carry out in-depth performance analysis of existing arsenic removal technologies installed in the area- district Rahim Yar Khan

3.2 To identify impediments in the sustenance of technology based arsenic removal technologies in the research area.

3.3 To identify non-technological options for safe drinking water and chalking out geo-hydrological protocol for alternative water supply options.

\section{Methodology}

Extensive critical analysis of existing in use / installed arsenic removal technologies (ARTs) in district Rahim Yar Khan, the arsenic contamination hit area, was carried out. The salient existing arsenic removal technologies are as under;

- $\quad$ Community based ARTs - 300 litters capacity tanks

- Households Level Clay Pitcher Arsenic Removal Filter

- Gravity flow arsenic removal cartridge Filter

- $\quad$ PUR Sachet

- $\quad$ Deep boring

All the above mentioned options were analyzed in the target area to evaluate the efficiency, acceptability and sustainability in the community for the development of sustainable community based arsenic mitigation system..

Socio-economic conditions of the target community, arsenic contamination affected population, was studied through focused discussion groups (FDGs), holding meetings with community resource persons and interacting with community notables.

Geo-technical soil data was obtained from the various government line departments and NGOs who were engaged in drilling bore holes in the area. Geo-technical data was analyzed for working out various non-technological options for getting arsenic free drinking water sources

\section{Result and Discussion}

Performance assessment / of following arsenic removal mitigation technologies, installed in district in district Rahim Yar Khan were evaluated;.

\subsection{Community Based Arsenic Removal Tanks (ARTs - Tanks )}

As the arsenic contamination was confirmed in the drinking water sources of district Rahim Yar khan during national arsenic survey programme - 2001-2004. Accordingly, a multi-prong arsenic mitigation strategies were launched by government line departments and NGOs, financially supported by UNICEF. Massive awareness raising campaigns for the common masses about the ill impacts of arsenic contamination on human health were launched. Arsenic contaminated sources were marked with red paint and safe water sources were marked with green paint and the water users were educated not to use water from red painted sources for drinking and cooking purposes. Besides this, 25 community based arsenic removal tanks units were installed for drinking purposes. The details of ARTs unit tanks are as under;

\subsubsection{ARTs (Arsenic Removal Technology) Unit}

ART is a community based water treatment unit, with 300 litters capacity, for safe drinking water designed by Pakistan Council of Research in Water Resources (PCRWR) which simultaneously removes arsenic, microorganisms and turbidity from the water. It comprises of two tanks made of stainless steel and filled with best available technology (BAT) / media) solution / gel, which filters the water through coagulation process. The complete ART unit in its installed form is shown in Figure-5, below;

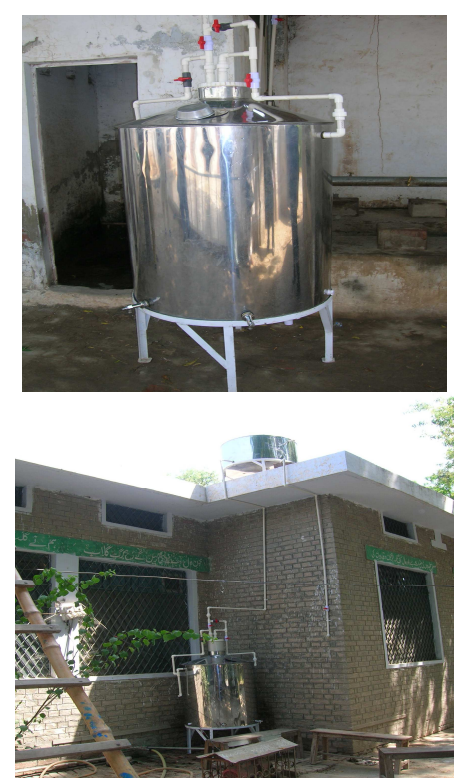

Figure 5. ART Water Treatment Unit for Safe Drinking Water 


\subsubsection{Component Description and Operation}

The treatment system comprises of following components;

\section{a. Reaction Tank}

It is a stainless steel tank of 300 litres capacity, raw water (containing arsenic, bacteria or turbidity) and chemical (BAT$01)$ are added in this tank for chemical reaction. It is usually kept high (4 to 5 feet) from filtered water reservoir, as shown in Figure-6, below;

\section{b. Drain Valve}

Drain valve of reaction tank is used to drain out the sludge from the reaction tank after the completion of chemical reaction, as shown in Figure-6, below;

\section{c. Filter}

It is used to filter the water from reaction tank. The filtration rate can be controlled by inlet valves (filter inlet valve, filtered water reservoir inlet valve)

\section{d. Backwash Line}

It is used to backwash the system, as shown in Figure-6, below ;

\section{e. Filtered Water Reservoir}

It is a stainless steel tank used to store the filtered water, fitted with taps for taking out the filtered water for drinking purpose, as shown in figure- 6 , below;

\section{f. Chemical (BAT-01)- The Filter Media- Ferric Chloride}

It is the chemical (BAT-01) stored in 20 litres cane, which is being used for the removal of Arsenic, Turbidity and Bacteria. Ferric Chloride gel is used in this treatment method as a coagulant for arsenic removal.

\subsubsection{Operation of $A R T$}

$a$. Fill the reaction tank with the water to be treated.

$b$. After shaking, add $150 \mathrm{ml}$ of chemical (BAT-01) with continuous stirring and give 40 minutes contact time to complete the precipitation process.

c. After 40 minutes, open the inlet valves of the filter and the filtered water reservoir.

$d$. When all the water from reaction tank has been filtered, open the drain valve of the reaction tank to drain the sludge and rinse the reaction tank to repeat the filtration process.
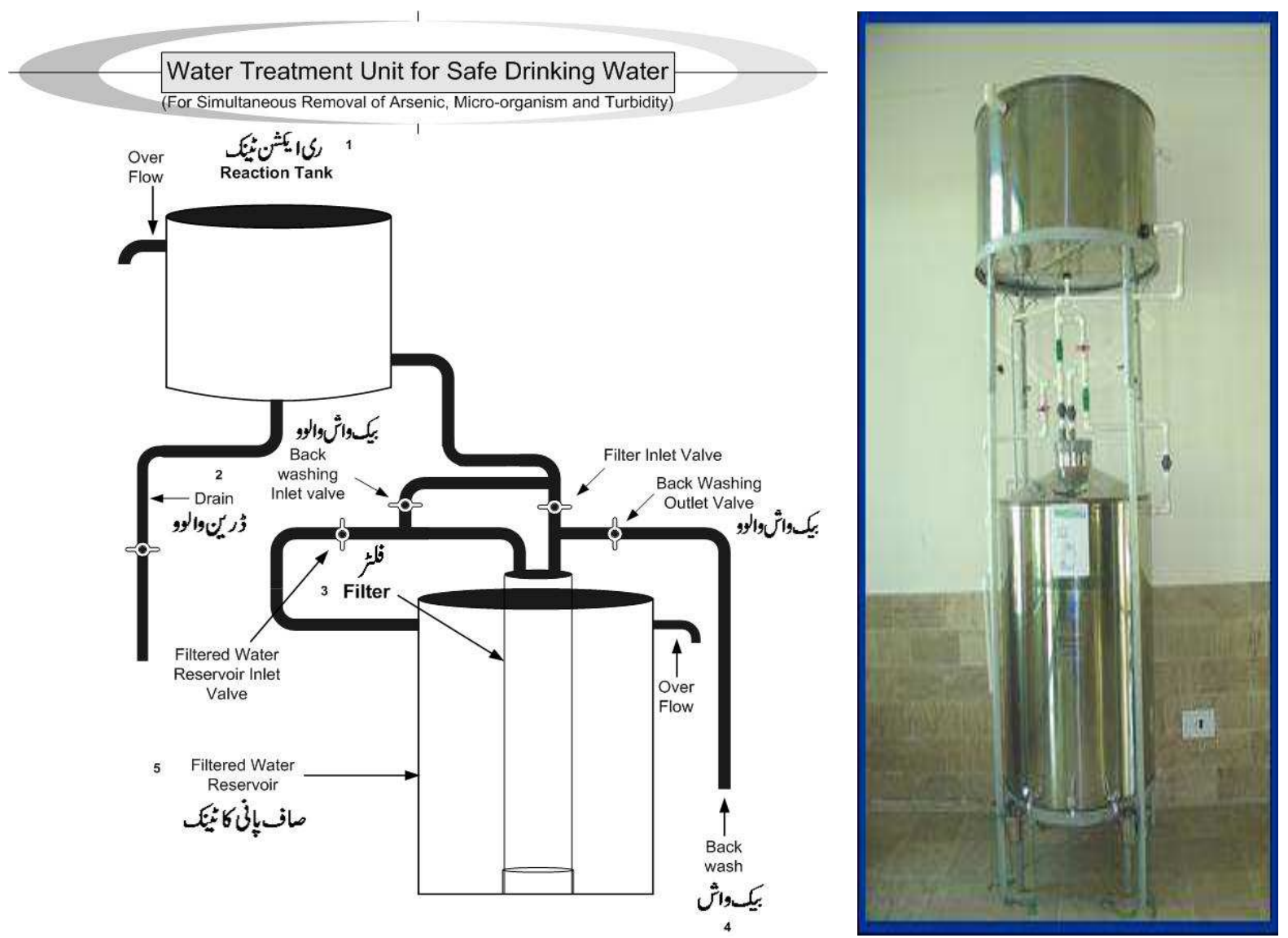

Figure 6. Schematic view of 300 litters arsenic removal unit (ART), showing various components

\subsubsection{Performance and Sustainability Assessment of ART Tanks Unit}

PCRWR with the financial support of UNICEF, installed approximately, 100 ARTS in the Punjab province of Pakistan, out of which, 25 ARTs were installed in the research area of district Rahim Yar Khan. A qualitative and quantitative monitoring was carried to check the following parameters;

a. Union Council, village and owner's name ( focal person made responsible for its operation and maintenance) 
$b$. Arsenic removal efficiency, status, functional or nonfunctional.

c. Community acceptability and physical conditions.

$d$. Reasons for non-functional $e$. Arsenic contamination before and after filtration.

The detailed monitoring observations are given in Table-1, as shown below;

Table 1. The performance status of 25 installed arsenic removal technologies

\begin{tabular}{|c|c|c|c|c|c|c|c|}
\hline \multirow{2}{*}{$\mathbf{S} \#$} & \multirow{2}{*}{ Village/Basti } & \multirow{2}{*}{ Owner's Name } & \multirow{2}{*}{ Status } & \multirow{2}{*}{ Condition } & \multirow{2}{*}{$\begin{array}{l}\text { Reason if not } \\
\text { functional }\end{array}$} & \multicolumn{2}{|l|}{ Arsenic ppb } \\
\hline & & & & & & Before & Before \\
\hline 1 & City Rajanpur Kalan & Govt Boys High School & Not Functional & Ok & Without any reason & 80 to 100 & Not Analyzed \\
\hline 2 & City Rajanpur Kalan & Govt Girls High School & Not Functional & Not Ok & Leakage from taps & 80 to 100 & Not Analyzed \\
\hline 3 & Rajanpur Kalan & Wajid Khan Dahir & Not Functional & Ok & Without any reason & 60 to 80 & Not Analyzed \\
\hline 4 & Basti Pathanastan & Mosque Bilal & Not Functional & Ok & $\begin{array}{l}\text { Chemical stock is } \\
\text { empty }\end{array}$ & 250 to 300 & Not Analyzed \\
\hline 5 & Basti Pahoran & Jam Akhter Hussain & Not Functional & Not Ok & $\begin{array}{ll}\text { Leakage } & \text { from } \\
\text { Reaction Tank } & \end{array}$ & 100 to 150 & Not Analyzed \\
\hline 6 & Basti Imam Nagar & Makhdum Sikandar & Not Functional & Ok & Use on every Sunday & 100 & Not Analyzed \\
\hline 7 & Basti Adam Machi & Nazim Hussain & Functional & Ok & & 100 to 150 & 20 \\
\hline 8 & Basti Haider Karar & Jamia Masjid & Not Functional & Ok & $\begin{array}{l}\text { No use in winter } \\
\text { season }\end{array}$ & 80 to 100 & Not Analyzed \\
\hline 9 & Iqbalabad & Ch Javed Iqbal & Functional & Ok & & 80 to 100 & 10 to 20 \\
\hline 10 & Iqbalabad & $\begin{array}{l}\text { Govt Girls Primary } \\
\text { School }\end{array}$ & Not Functional & Ok & $\begin{array}{l}\text { Disconnection of } \\
\text { Electricity }\end{array}$ & Not Analyzed & Not Analyzed \\
\hline 11 & Basti Dina & $\begin{array}{l}\text { Govt Girls Primary } \\
\text { School }\end{array}$ & Not Functional & Ok & Without any reason & Not Analyzed & Not Analyzed \\
\hline 12 & Basti Qadirabad & Master Ghulam Murtaza & Not Functional & Not Ok & Damage due to storm & 150 to 200 & Not Analyzed \\
\hline 13 & Basti Yar Muhammad & Mr. Abu bakar & Not Functional & Ok & Not owned & 200 & Not Analyzed \\
\hline 14 & Basti Rajpur & Madrisa Rasheedia & Not Functional & Not Ok & Taps leaking & 100 & Not Analyzed \\
\hline 15 & Basti Yar Muhammad & Mr. Niaz Ahmed & Not Functional & Ok & $\begin{array}{l}\text { No use in winter } \\
\text { season }\end{array}$ & 60 to 80 & Not Analyzed \\
\hline 16 & Basti Yar Muhammad & Haji Mukhtiar Ahmed & Functional & Ok & Not owned,now & 10 to 20 & 5 to 10 \\
\hline 17 & Basti Yar Muhammad & $\begin{array}{l}\text { Mr. Ghulam Murtaza } \\
\text { Khan }\end{array}$ & Not Functional & Ok & $\begin{array}{l}\text { Chemical stock is } \\
\text { empty }\end{array}$ & 80 to 100 & Not Analyzed \\
\hline 18 & Basti Yar Muhammad & $\begin{array}{l}\text { Govt Girls } \quad \text { Model } \\
\text { School }\end{array}$ & Not Functional & Not Ok & Damage due to storm & Not Analyzed & Not Analyzed \\
\hline 19 & Basti Bhura & Mian Khalid & Not Functional & Ok & $\begin{array}{l}\text { Chemical stock is } \\
\text { empty }\end{array}$ & 150 & Not Analyzed \\
\hline 20 & Basti Sultan & Saith Abdul Sattar & Not Functional & Ok & Servicing of unit & 80 to 100 & Not Analyzed \\
\hline 21 & $\begin{array}{l}\text { Basti Chah Khandu } \\
\text { Wali }\end{array}$ & Chah Khandu Wali & Not Functional & Ok & $\begin{array}{l}\text { Shifted on other site } \\
\text { by themselve }\end{array}$ & 100 to 150 & Not Analyzed \\
\hline 22 & $\begin{array}{l}\text { Basti } \quad \text { Muhammad } \\
\text { hashim }\end{array}$ & Muhammad Jamil & Not Functional & Ok & $\begin{array}{l}\text { Chemical stock is } \\
\text { empty }\end{array}$ & 100 to 150 & Not Analyzed \\
\hline 24 & Dhudhian & Haji Allah Dad & Functional & Ok & No media & 10 to 20 & 5 \\
\hline 25 & Basti Ch Nazir Ahmed & Ch Nazir Ahmed & Not Functional & Not Ok & Filter is choked & 80 to 100 & Not Analyzed \\
\hline
\end{tabular}

\subsubsection{Performance Analysis}

The arsenic removal technology (ART) tanks unit produced good results and arsenic removal efficiency was within the permissible limits. But due to certain reasons, as mentioned in the performance monitoring table-1, this project could not sustained longer. The details of major problems and causes of failure are as under;

a. Out of 25 ARTs, only 2 were found apparently functional and at the same time these were not being used / operated due to non-availability of filter media. Media, the gel of ferric chloride was not a marketable item and it was available only with Pakistan of Council of Research in Water Resources ( PCRWR), Islamabad which is located about $700 \mathrm{~km}$ away from the project site b. 8 ARTs were completely damaged due to sand storms and lack of ownership etc.

c. 6 ARTs, were found without water connection to filtration tank and without filter media .

d. 13 ARTs were found non-functional due to leakages in the piping network and non provisioning of electric connection.

$e$. Non-availability of BAT (media) at site which rendered the ARTs non functional.

f. Community could not test / check the efficiency of ART as they have no known how and required equipment / mechanism and arsenic testing field kits to carry out the periodic arsenic contamination testing .

$g$. Regular efficiency monitoring could not be maintained, therefore, it was difficult to know the exact performance. $h$. Non-existence of institutional arrangements for timely 
repair and maintenance. Particularly, non-availability of running spare parts.

$i$. Project scaling up could not take place, being nonmarketable item at the local market place, both ART tanks unit and filter media.
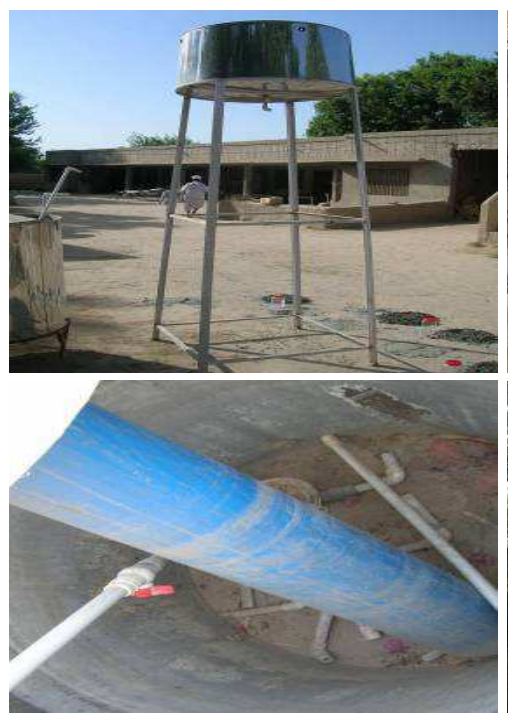

Figure 7. Damaged ARTs tanks which are non-functional and in dismantled conditions

\subsection{House Hold Filters (Clay-Pitcher)}

Pakistan Council of Research in Water Resources (PCRWR) and UNICEF collaborated in developing low- cost household level filters for treating arsenic contaminated water. Considering the socio-economic background of rural and urban populations in the arsenic affected areas, three options of low cost arsenic removal technologies (i.e. claypitcher, plastic gravity flow, and ceramic cartridge arsenic removal filters) were developed by PCRWR. Monitoring of these filters in a laboratory for a period of six months indicated that the clay pitcher arsenic removal filter was the most feasible technology with respect to arsenic removal efficiency, life of media used, estimated cost as well as simplicity and ease of use. It reduced arsenic from an initial value of 300 (before treatment) $\mathrm{ppb}$ to $0.2 \mathrm{ppb}$ (after treatment) at the beginning of the monitoring period and $j$. Non- willingness of the community to accept the change due to lack of education.

Therefore, after 9-12 months of their installations, the onground / physical status of the ARTs is depicted in figure-7, shown below;

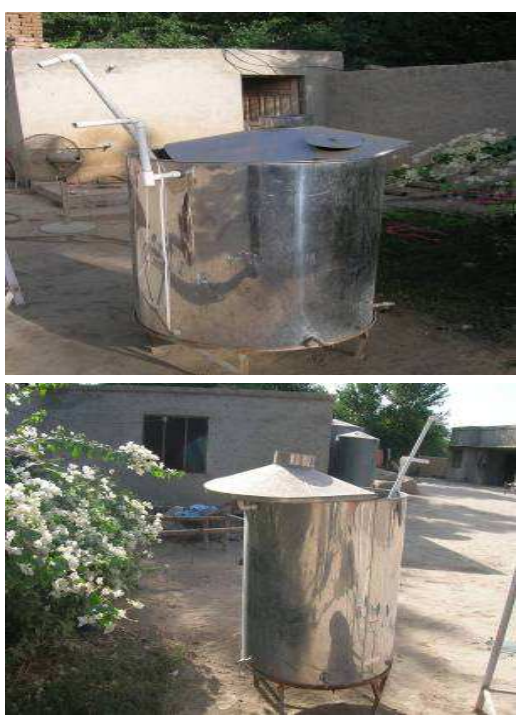

reduced it to $50 \mathrm{ppb}$ at the end of about six months thus determining the maximum useful life. The clay pitcher has a volume of about 20 liters. The clay pitcher has small holes, approximately there are $10-12$ holes of $1 \mathrm{~mm}$ diameter sufficient to maintain the flow within the required range. The cost of the filter, as estimated during the experimentation, is Rs. 400-600 (i.e., 7-10US\$). However, it is believed that it may reduce substantially on mass production at local level because production of a few units for the laboratory is expensive due to high fixed cost. This new technology requires promotion in the areas where there is no alternative safe, arsenic- free water available. In addition, more research needs to be carried out to provide a wide range of technologies meeting varying needs of consumers. The household filter (clay pitcher) and various media used are shown in Figure-8 \& 9, below;

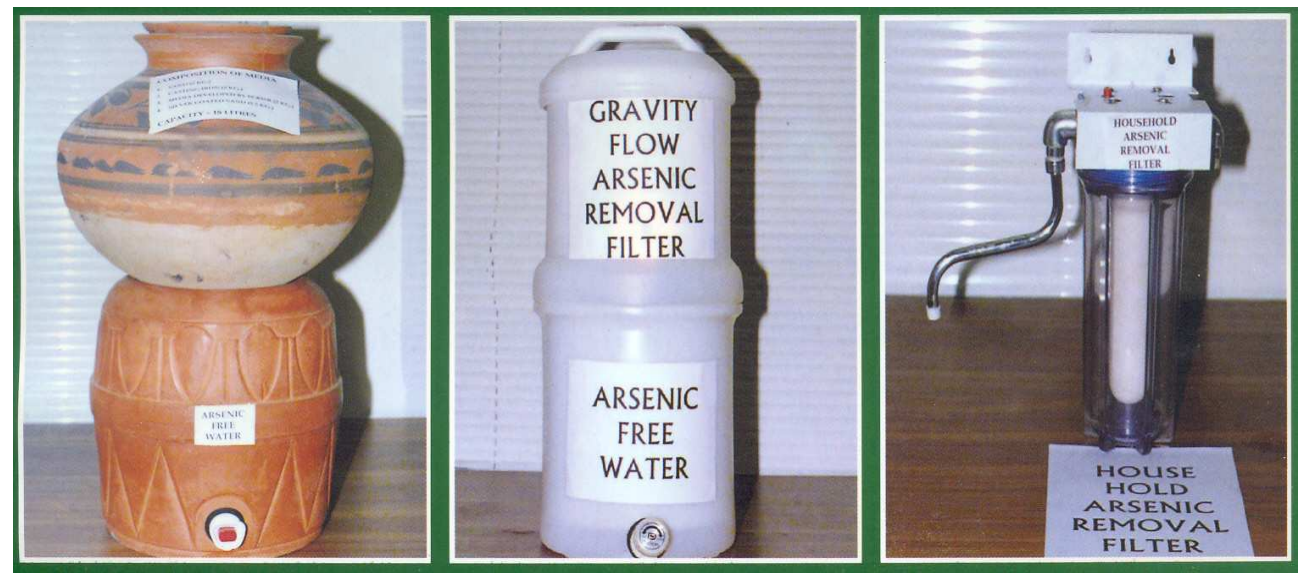

Figure 8. Clay pitcher and $r$ arsenic removal filters 


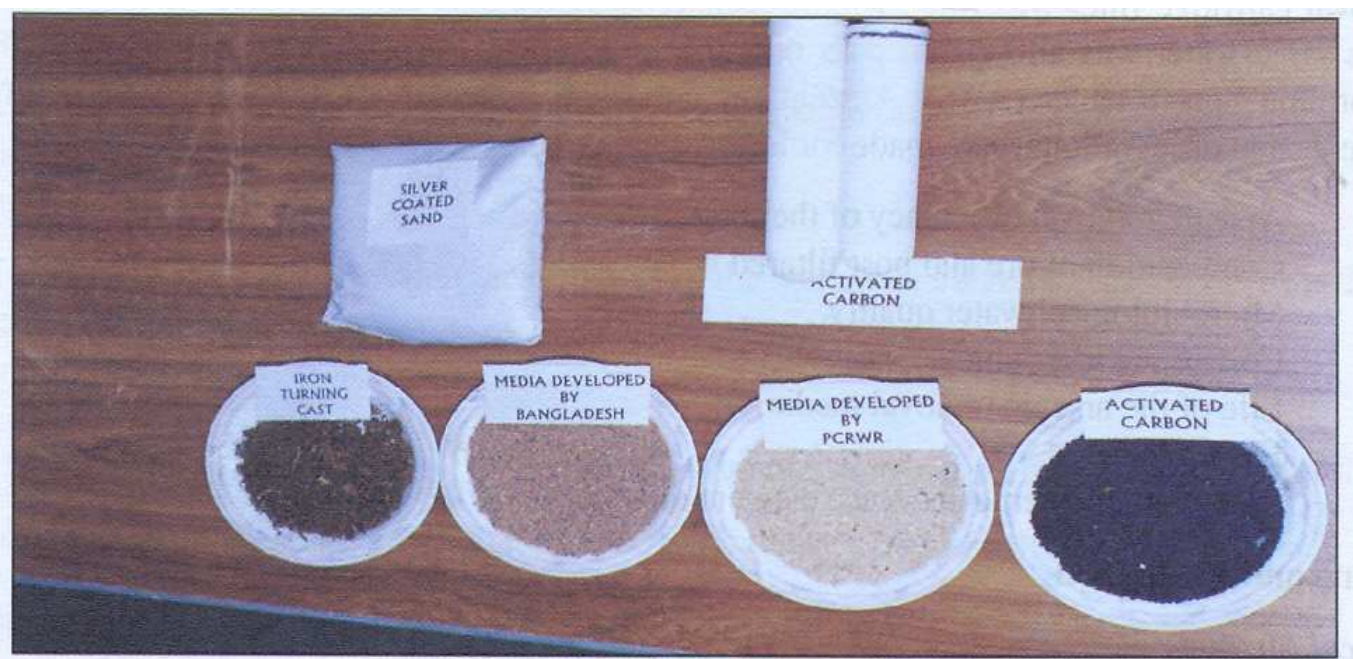

Figure 9. Different medias used for arsenic removal

\subsection{Gravity Flow Arsenic Removal Cartridge Filter}

This system consisted of two locally manufactured containers. The main container consists of an upper portion in which two ceramic cartridges (having arsenic removal media) can be fitted at a time to remove arsenic as well as microbiological contamination from water. Water is filtered into the lower vessel by gravity flow as shown in figure- 8 , above. It can be used in the areas where water supply is not available. This option is not available for community use.

\subsection{PUR Sachet}

It is a sachet packed with chemicals coagulant and disinfectant (Iron III Sulfate + Calcium Hypochlorite) which are effective for arsenic, bacteria and turbidity removal, manufactured by Procter \& Gamble (Pvt) ltd. One sachet is used for treatment of 10 litters of drinking water. UNICEF integrated this exercise to provide the additional option to the communities in those areas, where the drinking water is not safe and contaminated. UNICEF provided the supplies including sachet, with relevant accessories for making the safe water at household levels. These sachets were distributed among the 264 families in 10 villages of Union Council Rajanpur Kalan, tehsil \& district Rahim Yar Khan. The demonstration of use of Pur sachet is shown in Figure-10, below;

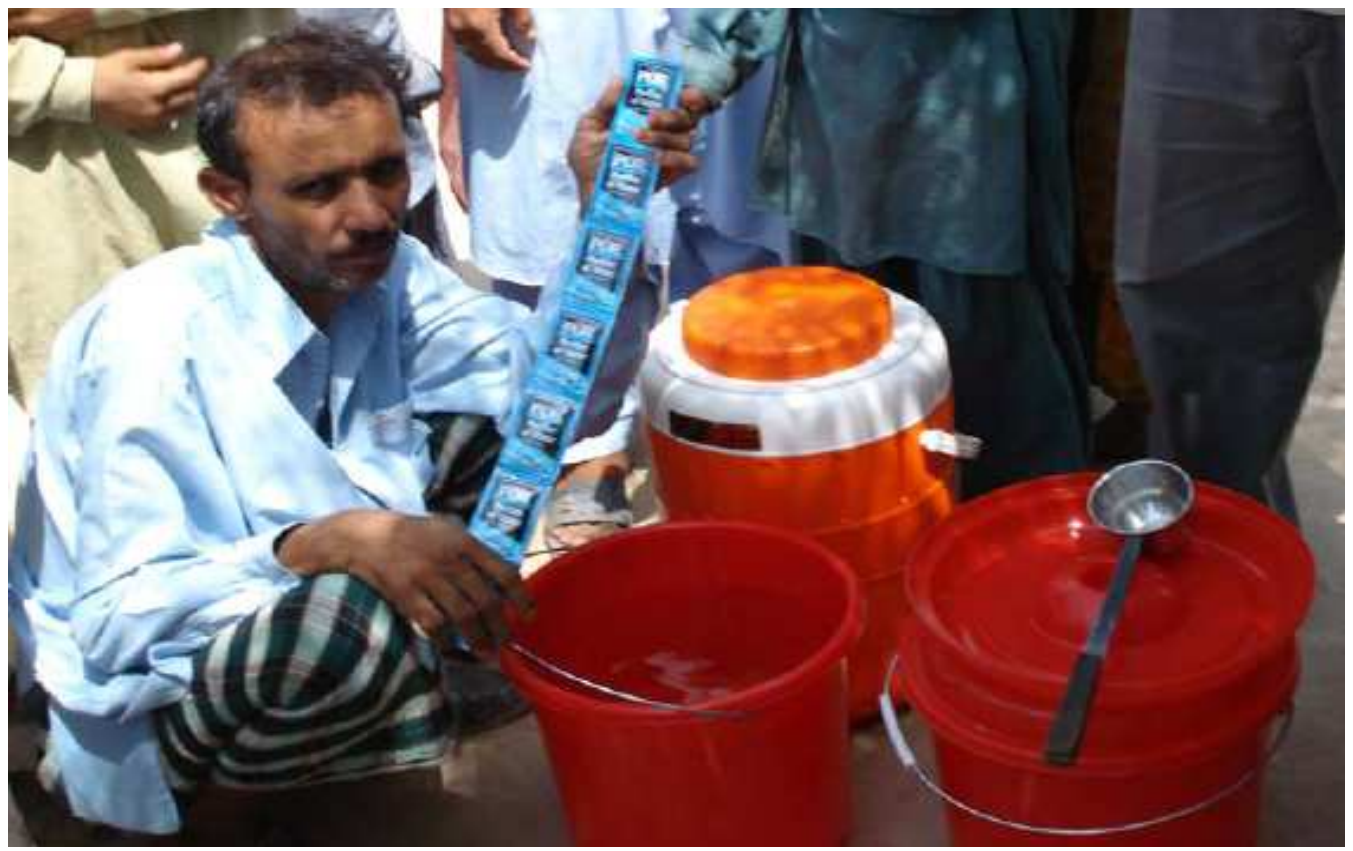

Figure 10. Demonstration on use of PUR sachets

\subsection{Deep Boring}

Continuous monitoring of the deep well at the depth of 380 feet was monitored for one year which showed arsenic concentration $<10 \mathrm{ppb}$. It was observed that the arsenic concentration decreases with the increase in bore depth. The 
soil analysis showed no evidence of presence arseno-pyrites and most probable causes of arsenic contamination in the area is due to leaching effects of sustained application of pesticides and fertilizers which is quite possible ((Sharma, A.K., 2006). Therefore, the possible reasons may be of industrial activities in these districts. There are a number of pesticides, fertilizers, chemical, agricultural and other industries established in Rahim Yar Khan. So the industrially induced arsenic pollution due to drainage of industrial wastes especially of pesticide industries may be possible cause of arsenic in groundwater. The relationship between arsenic concentration and bore depth in the area is shown in figure11, below

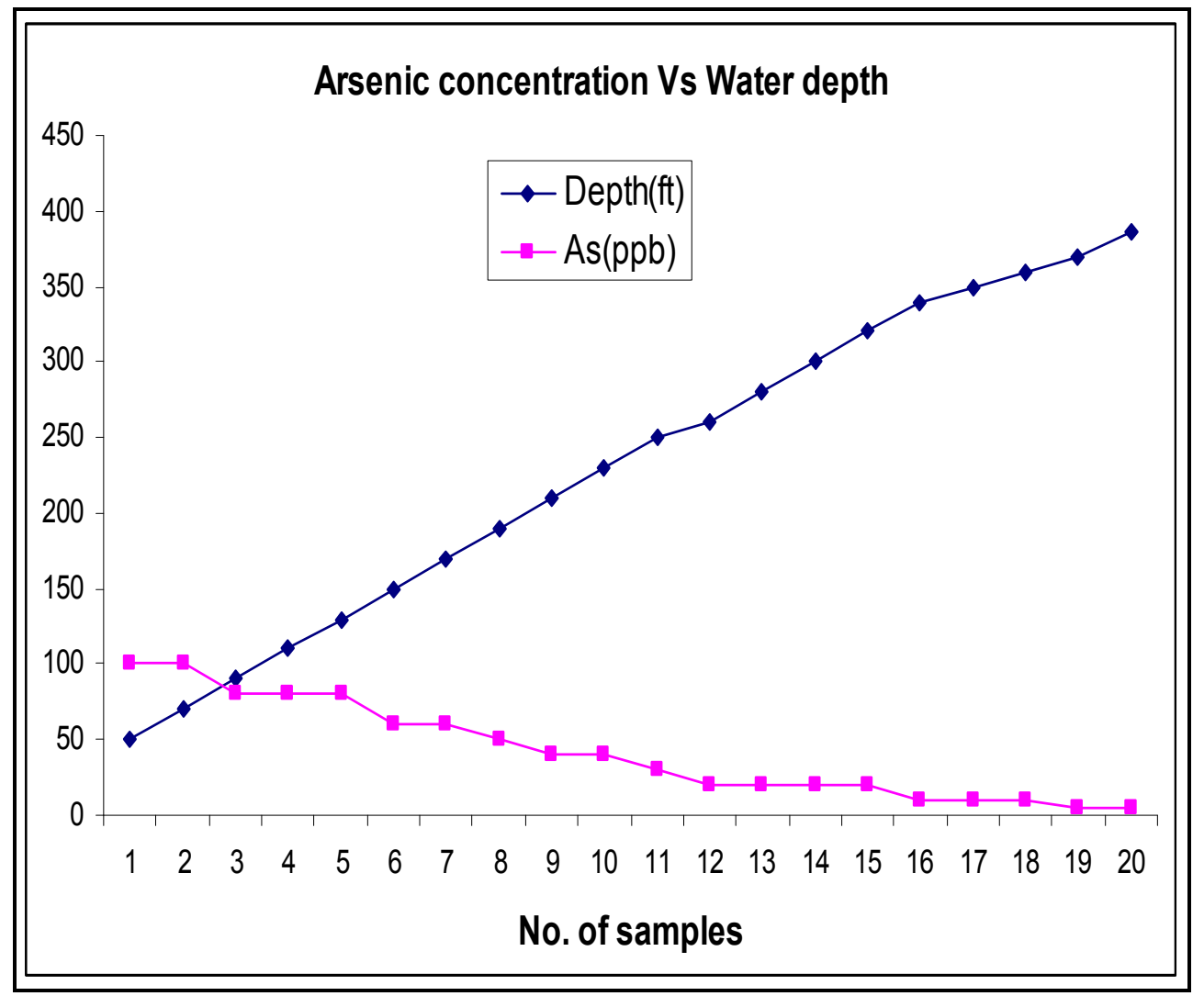

Figure 11. The decrease in ground water arsenic concentration verses bore depth

The critical performance monitoring /analysis pertaining to their workability, efficiency and sustainability indicates that the existing and installed arsenic removal technologies (ARTs) in arsenic hit areas of Pakistan, has proved to be non-viable and un-sustainable options for provisioning of arsenic free water due to the following reasons;

$a$. The poor socio-economic conditions of the people, like low literacy rate and low income diminishes the will to understand the ill-impacts of arsenic contamination on human health amongst the community.

$b$. Lack of resources, both technical and financial, are the dominating factor in maintaining the installed arsenic removal facilities.

c. Behavioral change communication strategies for adaptation of safe drinking water practices were undertaken as a onetime measure, which could not change the mindset of the arsenic contamination affected people.

$d$. Mostly, people living in the remote rural areas are technology shy people and prefer/ welcome those interventions which are compatible with their socioeconomic environments. $e$. The most sustainable alternative arsenic free option was found to be deep boring which is compatible with the socio-economic environments of the local population, as ground water is a major source for agriculture practices through shallow deep bores. Therefore, the community is to be advised to go for deep boring , rather than relying / confining on shallow aquifers and this will provide arsenic free water for drinking purposes and for other human needs.

\subsection{Alternative Arsenic Free Water Supply Options Protocol}

Once arsenic contamination has been identified in a water supply and areas of contamination prioritized according to the degree of risk the water supply poses to the population consuming it, solutions-both stop-gap and long-term must be provided. Mostly, the government and donor agencies opt for technology based arsenic mitigation interventions which in most of the cases, becomes un-sustainable due to lack of ownership by the community and the government. Though community is the major stakeholder and should own the 
facility, but due to lack of resources, technical knowhow and non-availability of running spare parts, the arsenic filtration plants becomes un-sustainable. Therefore, before going for technology based solutions for provisioning of arsenic free water, availability of alternative sources of water supply in that area be examined. In Pakistan, the planned alternative water supply activities are based on the following facts and assumptions;

a. The available alternative water supply and arsenic removal technology options are area dependent and cannot be prioritized for the whole country. The country is broadly divided in shallow water table areas, low water table areas, coastal saline areas, and mountainous areas requiring technological variations.

$b$. No single option will suit for every place in the prospective of different social and economic conditions, therefore community choice should be given priority in the selection of alternative water supply or technological options.

$c$. Illiteracy and knowledge gaps in some areas will impede decision making regarding selection of alternative technologies for arsenic affected areas and assured sustainability of the interventions / projects - in post project scenarios.

d. In some areas, mix of both technology based and alternative water supply options are best suited .

Therefore, the following component frame work for alternative water supply is suggested and described as in figure-12, below;

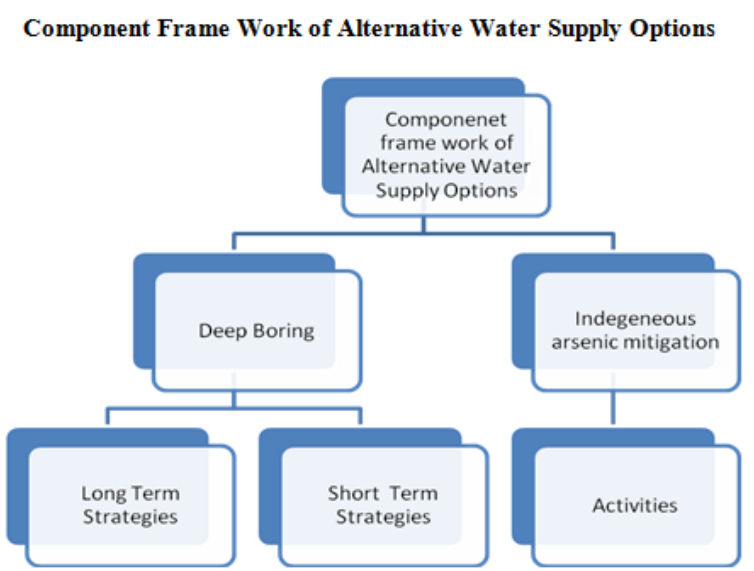

Figure 12. Component frame work of alternative water supply options

\subsubsection{Deep Boring}

During the course of arsenic testing, it was found that mean arsenic concentration in shallow water sources $(<100$ feet) was higher than the deeper water sources ( $>100$ feet). Moreover, the proportion of water sources with concentration above the permissible level was higher in shallow ( $<100$ feet) sources than the deeper sources $(>100$ feet). The mean age of water sources having arsenic concentration above permissible level was significantly greater than of the sources within the permissible level (50 ppb). These significant findings will facilitate in deciding the suitable arsenic mitigation strategies.

\subsubsection{Short-Term Strategies}

The short-term and immediate actions for provisioning of arsenic free water are summarized in figure-13, below;

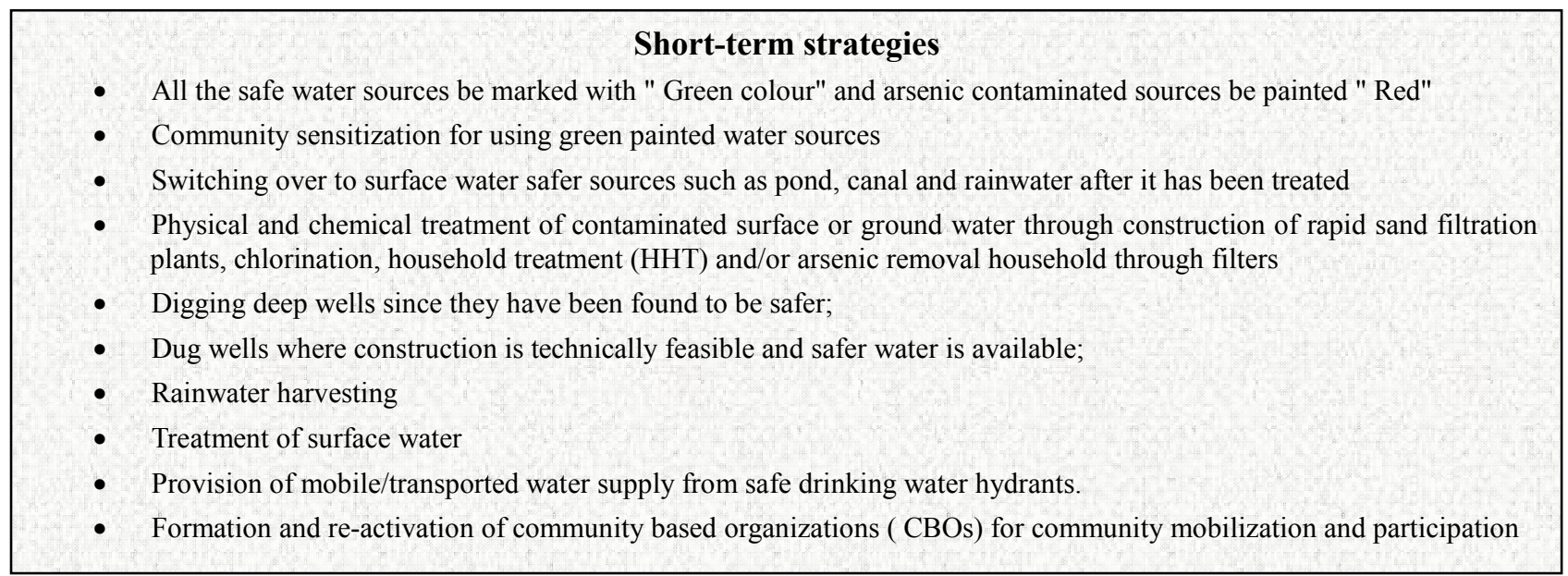

Figure 13. Short-term strategies for provisioning of alternative water supply measures.

\subsubsection{Long-Term Alternative Safe Water Supply Options}

Long-term options in areas with arsenic contamination problems include provision of piped water supply from arsenic-safe sources, development of new treatment technologies for communities, prevention through early detection of arsenic contamination of water sources and encouragement of changes in behaviors among affected communities to use the arsenic-safe water for drinking and cooking.

Micro-watershed management projects be planned and implemented for rain water harvesting which will be good enough to meet the drinking water needs, after treatment, and small scale agricultural purposes.

For alternative water supply options, following projected activities are suggested, as described in table-2, below; 
Table 2. Summary of projected activities for alternative water supply options, both short \& long term

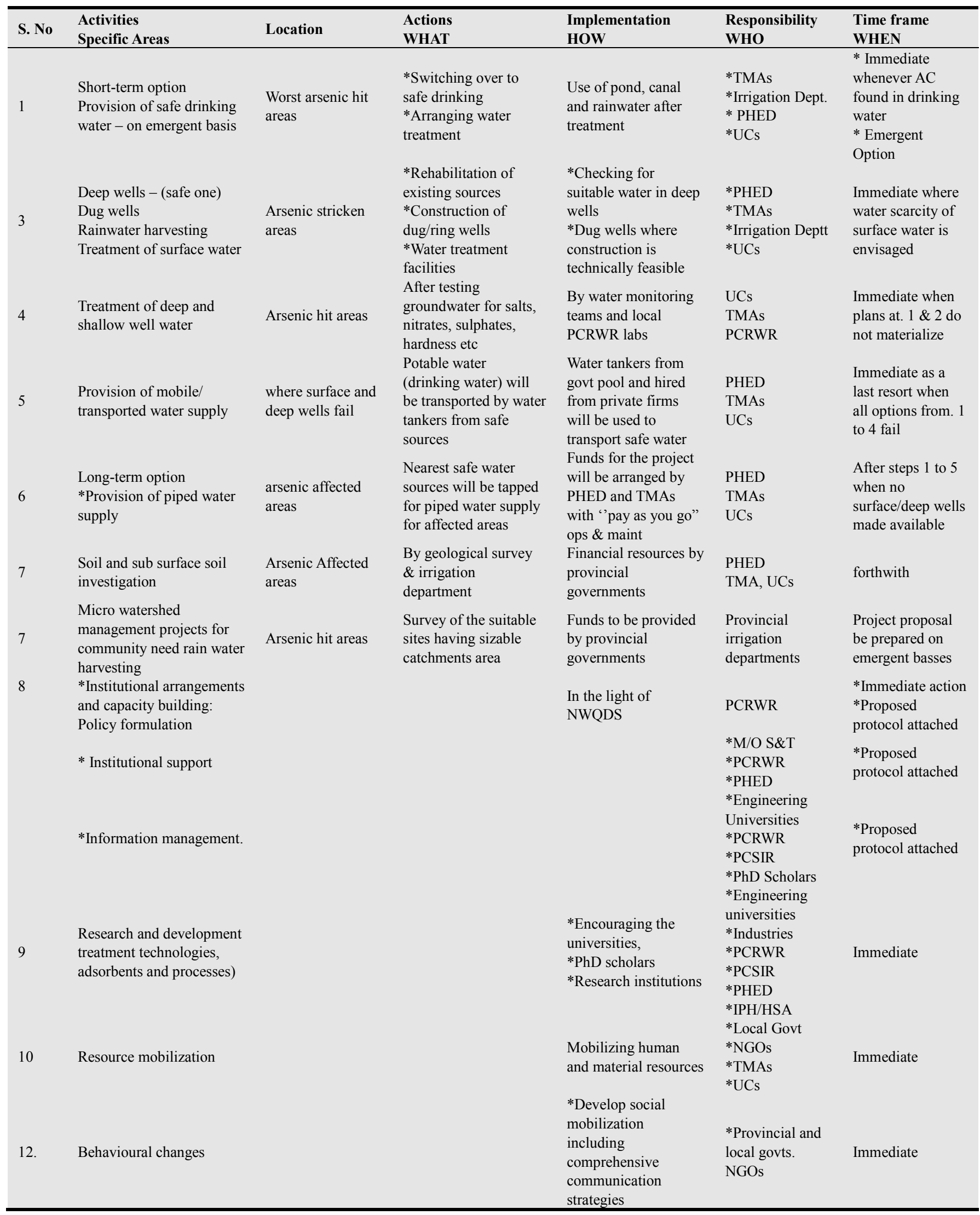




\subsubsection{Proposed Strategies for Development of an Indigenous Technology Based Arsenic Mitigation System}

Meanwhile, the usefulness of technological based arsenic mitigation measures cannot be overlooked, as the causes of ground water arsenic contamination depends on soil configuration / composition which varies area to area. In case of presence of arseno-pyrites in the sub-soil strata, then all out endeavors be made to exploring the possibilities of indigenous arsenic removal technologies, which are easily available in the local market, particularly filter media / adsorbents, and have the community accessibility

In this case, research institutions etc be involved for finding out locally available adsorbent material, like iron rich sand and some sort of plant species etc which can remove the arsenic from drinking water . Proposed strategies for development of an indigenous arsenic mitigation system are shown in Table -3, below;

Table 3. Summary of activities for development of an indigenous arsenic mitigation system

\begin{tabular}{|c|c|c|c|c|}
\hline Activities & Location WHERE & ACTION HOW & Responsibility WHO & $\begin{array}{l}\text { Time frame/Remarks } \\
\text { WHEN }\end{array}$ \\
\hline $\begin{array}{l}\text { Geo-technical soil analysis } \\
\& \text { investigation }\end{array}$ & Arsenic affected areas & $\begin{array}{l}\text { - Studying available } \\
\text { soil data } \\
\text { - Drilling deep bore } \\
\text { hole and taking soil } \\
\text { samples at } 10 \text { feet } \\
\text { intervals }\end{array}$ & Geological survey of Pakistan & Immediate action \\
\hline $\begin{array}{l}\text { Selection of cost-effective } \\
\text { available technologies }\end{array}$ & Office/lab / field trials & $\begin{array}{l}\text { Comparing the } \\
\text { advantages and } \\
\text { disadvantages }\end{array}$ & $\begin{array}{l}\text { All institutions and individual } \\
\text { researchers }\end{array}$ & $\begin{array}{l}\text { Sharing of knowledge by all the } \\
\text { establishments / institutions }\end{array}$ \\
\hline $\begin{array}{l}\text { Screening of absorbents as } \\
\text { adsorption process is } \\
\text { selected best }\end{array}$ & $\begin{array}{l}\text { Laboratory test and } \\
\text { literature review }\end{array}$ & & $\begin{array}{l}\text { All institutions and individual } \\
\text { researchers }\end{array}$ & $\begin{array}{l}\text { The list of the available } \\
\text { adsorbents is shown in } \\
\text { appendix } 3\end{array}$ \\
\hline $\begin{array}{l}\text { Laboratory testing and } \\
\text { trials }\end{array}$ & Laboratory & & $\begin{array}{l}\text { All institutions and individual } \\
\text { researchers }\end{array}$ & $\begin{array}{l}\text { EPA, PCRWR and NGOs must } \\
\text { finance individual researchers }\end{array}$ \\
\hline $\begin{array}{l}\text { Construction of prototype } \\
\text { mitigation system }\end{array}$ & $\begin{array}{l}\text { Laboratory and in worst } \\
\text { hit areas }\end{array}$ & & $\begin{array}{l}\text { PCRWR, and individual } \\
\text { researchers }\end{array}$ & $\begin{array}{l}\text { Well established institutions } \\
\text { must share the knowledge and } \\
\text { encourage the research }\end{array}$ \\
\hline $\begin{array}{l}\text { Construction of the full- } \\
\text { scale arsenic mitigation } \\
\text { system in affected areas. }\end{array}$ & $\begin{array}{l}\text { In worst hit arsenic } \\
\text { contamination areas, as a } \\
\text { first priority. }\end{array}$ & & $\begin{array}{l}\text { MoE, PCRWR, LG/TMAs, } \\
\text { Universities and individual } \\
\text { researchers }\end{array}$ & $\begin{array}{l}\text { After installation of the } \\
\text { mitigation system, local } \\
\text { community be involved for } \\
\text { operation and maintenance, } \\
\text { immediately for } 5 \text { years }\end{array}$ \\
\hline $\begin{array}{l}\text { Designing behavioural } \\
\text { change communication } \\
\text { strategies }\end{array}$ & In arsenic affected areas & $\begin{array}{l}\text { Should based on the } \\
\text { knowledge, Aptitude } 7 \\
\text { practices ( KAP) } \\
\text { survey findings }\end{array}$ & $\begin{array}{l}\text { By engaging social sciences } \\
\text { institutions \& consultants }\end{array}$ & Immediate action \\
\hline
\end{tabular}

\section{Conclusions}

Ground water arsenic contamination in several countries has emerged as a big public health nuisance and its mitigation is being taken seriously. Proto type mitigation strategies are suitable for all areas, countries and communities. The biggest impediments in the success and sustainability of mitigation measures are the low socioeconomic conditions of the affected communities who are technology shy and un-able to maintain \& own the installed arsenic mitigation technologies. Therefore, before going for any technological solution, socio-economic survey of the inhabitants be carried out to ascertain the sustainability of the interventions, alongwith detailed soil investigation. Soil investigation will facilitate in deciding for deep boring option which is otherwise sustainable and compatible with the socio-economic environments of the poor rural communities.

\section{Acronyms}

\begin{tabular}{|c|c|}
\hline RT & Arsenic Removal Technology \\
\hline $\mathrm{AC}$ & Arsenic Contamination \\
\hline EPA & Environmental Protection Authority \\
\hline HHT & Household treatment \\
\hline HSA & Health Services Academy \\
\hline IPH & Institute for Public Health \\
\hline $\mathrm{M} / \mathrm{O} \mathrm{S} \& \mathrm{~T}$ & Ministry of Science \& Technology \\
\hline NWQDS & $\begin{array}{l}\text { National Water Quality Drinking } \\
\text { Standards }\end{array}$ \\
\hline PCRWR & $\begin{array}{l}\text { Pakistan Council of Research in Water } \\
\text { Resources }\end{array}$ \\
\hline PCSIR & $\begin{array}{l}\text { Pakistan Council of Scientific and } \\
\text { Industrial Research }\end{array}$ \\
\hline HED & $\begin{array}{l}\text { Public Health Engineering Department } \\
\text { parts per billion }\end{array}$ \\
\hline
\end{tabular}


TMA Tehsil Municipal Administration

TMO Tehsil Municipal Officer

UNICEF United Nations Children's Fund

WHO World Health Organization

\section{References}

[1] Ahmad, J., Golder, B., \& Misra, S. (2005). Value of arsenicfree drinking water to rural households in Bangladesh. Journal of Environmental Management, 74(2), 173-185. http://dx.doi.org/10.1016/j.jenvman.2004.07.011

[2] Islam ul Haq, Waqas Hanif, Ghalib Hasnain, Shahid Durez (2012), Socio-economic Impacts on Human Life in Arsenic Affected Area of Basti Rasul Pur, Rahim Yar Khan, Pakistan, Sustainable Agriculture Research; Vol. 1, No. 2; 2012 ISSN 1927-050X E-ISSN 1927-0518 Published by Canadian Center of Science and Education
[3] Nahar, N., Hossain, F., \& Hossain, M. D. (2008). Health and socio-economic effects of groundwater arsenic contamination in rural Bangladesh: Evidence from Field Surveys. Journal of Environmental Health (in press).

[4] Park, K. (1997). Text book of Preventive and Social medicine. (15th ed.). p. 469. Banarsidas Bhanot Pub.

[5] WHO. (2001). Report of the commission on macroeconomics and health. Geneva.

[6] Md. Akramul Alam et al - Assessment of Dugwell as an Alternative Water Supply Options in Arsenic Affected Areas of Bangladesh, International Journal of Civil \& Environmental Engineering IJCEE-IJENS Vol: 11 No: 01

[7] Mustafa Moinuddin, ACDIS Occasional Paper, 2004. Arsenic Contamination as a Threat to Water Security for Bangladesh 